Department of Zoonotic Diseases,

National Research Centre, Egypt

\title{
THE EFFECT OF CLINDAMYCIN AND SULFADIAZINE ON EXPERIMENTAL MURINE MODEL WITH ACUTE TOXOPLASMOSIS
}

(With 3 Tables and 4 Figures)

By

\section{A.M.A. BARAKAT and SYLVIA O. AHMED*}

*Dept. of Animal Hygiene and Zoonoses, Faculty of Veterinary Medicine, Assiut University, Egypt.

(Received at 15/9/2010)

\section{تأثير الكلينداميسين والسلفاديازين على فئران التجارب المعدية بداء التكسوبلازموزيس (الطور الحاد)}

\section{أشرف بركات ، سبلئيا أحد}

مرض التكسوبلازما من الأمر اض المشتركة التى لها أهمية كبرى عند الانسان و الحيوان. الطفيل

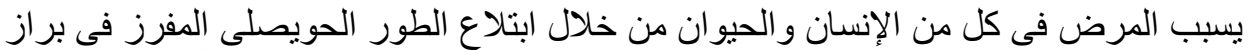

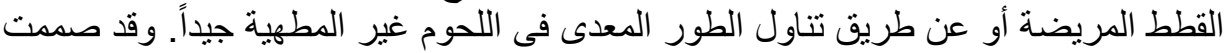

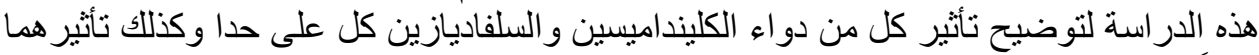

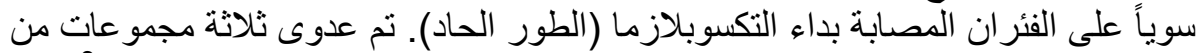

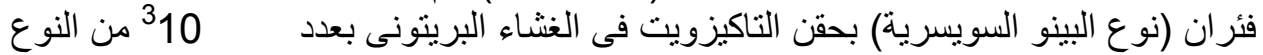

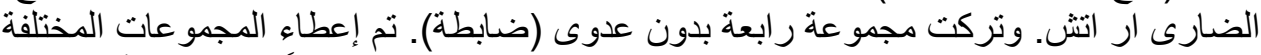

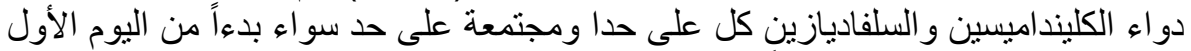

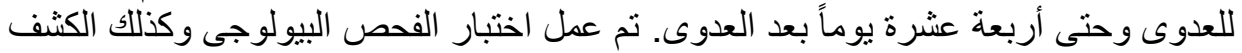

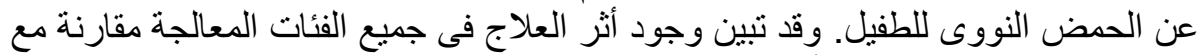

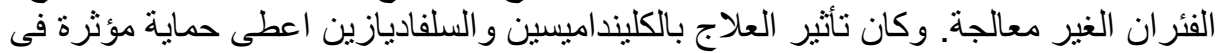

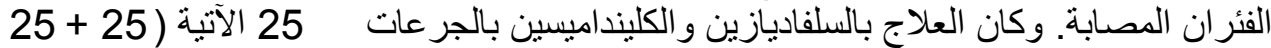

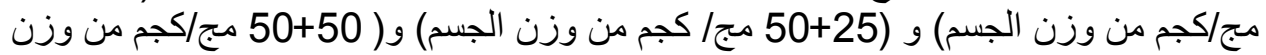

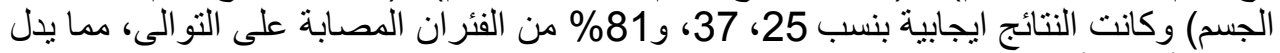

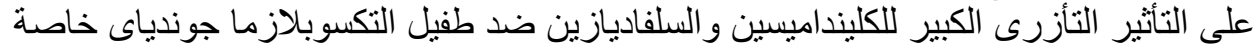
فى حالات العدوى الحادة.

\section{SUMMARY}

Toxoplasmosis has zoonotic importance among human and domestic animals. It causes diseases in both man and animals through ingestion of oocysts that passed in faeces of cat or by ingestion of cysts in undercooked 
meat. The present study was designed to clarify the effect of Clindamycin (CLI) combined with Sulfadiazine (SD) on a murine model of acute toxoplasmosis. Albino Swiss mice were intraperitoneally infected with $10^{3}$ tachyzoites of the RH strain of Toxoplasma gondii and were per orally treated with either drug alone (SD) or (CLI) or both combined. Starting with day 1 for 14 days. Survival was monitored during 8 weeks. Residual infection was assessed by a bioassay of representative 4-week survivors and by parasite DNA detection using PCR for representative 8-week survivors. An effect of treatment was shown in all treated groups compared to untreated control mice. Among mice infected with parasite, SD and CLI at any dose combination protected more animals. However, treatment with SD plus CLI at 25 plus 25,25 plus 50 , and 50 plus $50 \mathrm{mg} / \mathrm{kg} /$ day protected 25,37 , and $81 \%$ of mice, respectively, thus demonstrating a significant synergistic effect of SD and CLI against $T$. gondii especially in cases of acute infection.

Keywords: Toxoplasma gondii, Clindamycin, Sulfadiazine. PCR.

\section{INTRODUCTION}

Toxoplasmosis is one of the most common \& opportunistic parasite with zoonotic importance (Tenter et al., 2000). Toxoplasma gondii is an obligate intracellular protozoon parasite capable of infecting many species of mammals (Obata 1996; Dubey1981 and Hassanain et al., 1996). It causes diseases through ingestion of oocysts that passed in faeces of cat or by ingestion of cysts in undercooked meat (Johnson et al., 1990) and (Tenter et al., 1992) (Antonion et al., 1995) (Hejlicek, and Literak 1995) (Paniker 2002). Toxoplasma gondii ranks among the 10 most commonly occurring opportunistic infections and emerged due to the latent infection in immunosuppressant hosts (Barakat et al., 2009). Also fatal toxoplasmosis might occur after acute illness in domestic animals (Dubey et al., 1992). Toxoplasma gondii encephalitis is an important and estimated to occur in 20.000 to 40.000 patients with acquired immunodeficiency syndrome in USA. (Daniel et al., 1990).

The standard therapy for toxoplasmosis infection is pyrimethamine (PYR) and sulfonamides could adequately treat toxoplasmosis using a murine model of acute toxoplasmosis was infected intraperitoneally with $10^{4}$ parasites of the RH strain of Toxoplasma gondii (Louis et al., 1999). (Araujo et al., 1992) stated that the effect of Azithromycin or sulfadiazine were did not provide any protection against death due to toxoplasmosis, while in combination remarkably and significantly synergistic action. 
Also common used of antibiotics include pyrimethamine, trisulfapyrimidines, sulfadiazine, Clindamycin, and minocycline especially in cases of toxoplasmosis. Standard treatment with pyrimethaminesulfadiazine is often, requiring discontinuation of the drugs (Haverkos 1987; Leport et al., 1988). Clindamycin (CLI) is an alternative drug widely used as a single agent or combined with sulfa drugs (Dannemann et al., 1992; Dannemann et al., 1988). It has remarkable but delayed in vitro antiT. gondii activity, achieved at low drug concentrations (Pfefferkorn et al., 1992).

In addition to the well-established anti- $T$. gondii activity of CLI as a single agent in animal models of infection (Araujo and Remington 1974; Filice and Pomeroy 1991; McMaster et al., 1973; Vuković et al., 1997), doses of CLI that were ineffective when used alone was shown to afford protection in acute murine toxoplasmosis if combined with rifabutin (Araujo et al., 1994). The combinations of CLI with the others drugs was provided by reports on the activity against both tachyzoites and bradyzoitecontaining T. gondii cysts (Araujo et al., 1991; Araujo et al., 1992 and Gormley et al., 1998). In addition, has been shown to enhance the anti- $T$. gondii activity of pyrimethamine and sulfadiazine (Araujo et al., 1993), as well as that of rifabutin (Araujo et al., 1994 and Romand et al., 1996). The action of the sulpha and CLI acting as competitive inhibitors of $p$-amino benzoic acid (PABA) especially in the folic acid metabolism cycle. The sulfonamides are widely distributed throughout all tissues. CLI, which inhibits protein synthesis on prokaryotic ribosome's (Fitzhugh 1998). (Pfefferkorn and Borotz. 1994) stated that CLI act on the T. gondii prokaryote-type plastid-like organelle. Finally (Tsai et al., 2002) who was successfully treated for brain abscess with CLI and sulfadiazine.

Thus, we examined in vivo experimental model of acute toxoplasmosis whether the addition of SD to CLI would be beneficial for its anti- $T$. gondii effect and, moreover, if this combination is capable of eliminating the parasite, as suggested in the present work was planned to this study.

\section{MATERIALS and METHODS}

\section{Mice}

Female Albino mice (Laboratory Animal House National Research Centre, Cairo Egypt) weighing 18 to $20 \mathrm{~g}$ at the beginning of each experiment were used. Mice were housed six to a cage and offered drinking water ad libitum. 


\section{T. gondii}

Tachyzoites of the virulent RH strain maintained through serial intraperitoneally (I.P.) passages were used. For experimental infections, tachyzoites were harvested from mouse peritoneal fluids 72 hours post infection and purified by centrifugation, cotton wool filtration, and needle extraction. The parasites were counted in a hemocytometer, and their numbers were adjusted to $2 \times 10^{6} / \mathrm{ml}$ with saline. Suspensions were serially 10 -fold diluted and $1-\mathrm{ml}$ aliquots of $2 \times 10^{3} / \mathrm{ml}$ dilutions were inoculated I.P. into fresh mice.

\section{Drugs}

High efficacy of Clindamycin (CLI) combined with Sulfadiazine (SD) based therapies was demonstrated for treatment of experimental Toxoplasma gondii infection. Mice were infected intraperitoneally with $2 \times 10^{3} T$. gondii strain RH tachyzoites.

Group: I. SD (micronized powder, was administered at, 25, 50, and 100 $\mathrm{mg} / \mathrm{kg} / \mathrm{day}$.

Group II: CLI was administered at 25, 50, and $100 \mathrm{mg}$ per $\mathrm{kg}$ of body weight per day.

Group III: SD + CLI were administered at 25 plus 25,25 plus 50, 50 plus 50 , or 50 plus 100 and 100 plus $100 \mathrm{mg} / \mathrm{kg} / \mathrm{day}$.

Group IV: left without treatment (control).

Based on the observation that mice consume $4 \mathrm{~g}$ of food per day (Filice and Pomeroy 1991and McMaster et al., 1973), per $1 \mathrm{~g}$ of ground mouse feed.

\section{Experimental protocol}

Mice injected I.P. with $10^{3}$ parasites was arbitrarily assigned to one of the 12 treatment groups according to the treatment given, as follows: 3 doses as described previously.

To assess residual infection in mice treated by Clindamycin with sulfa, groups of two arbitrarily chosen survivors were sacrificed into two times:

(First): 4 weeks post infection, for sub-inoculation of brains into fresh mice to attempt re- isolation of $T$. gondii (bioassay), and

(Second): 8 weeks post infection, for the detection of $T$. gondii DNA in brains and lungs by PCR. Brains and lungs were chosen as likely reservoirs of parasites following treatment of murine infection (Piketty et al., 1990). Each treatment group comprised 12 animals. Treatment was initiated $24 \mathrm{~h}$ following parasite inoculation and was continued for 14 consecutive days. A group of untreated animals served as the negative control. 


\section{Bioassay}

Brains were homogenized, and $0.5-\mathrm{ml}$ saline suspensions were inoculated into two fresh mice per sample, one each by the I.P. and intraoesophageal routes. Mice were monitored daily over 4 weeks; peritoneal fluids of those succumbing were examined for the presence of T. gondii.

\section{PCR assay}

For DNA extraction, mouse brains and lungs were dilacerated and suspended in a lysis buffer containing $200 \mathrm{mM}$ Tris-HCl, $1 \mathrm{mM}$ EDTA, 0.5 $\mathrm{M} \mathrm{NaCl}, 1 \%$ sodium dodecyl sulfate, and $5 \mathrm{mg}$ of proteinase $\mathrm{K} / \mathrm{ml}$. The extraction procedure was conducted according to a classical protocol (Maniatis and Sambrook 1982).

PCR technique was carried on formalin-fixed, paraffin-embedded tissue samples showing histopathological changes. Formalin-fixed tissue samples were washed twice with phosphate buffer saline (PBS) to remove fixative, while paraffin-embedded tissue was treated with xylene followed by absolute alcohol. Then tissue samples were digested using a commercially available kit (QIAamp ${ }^{\circledR}$ DNA Mini kit, QIAGEN, INC., Valencia, CA) using the tissue protocol recommended by the manufacturer, prior to assay by PCR. $5 \mu 1$ of supernatant fluid was used in the first stage of a nested PCR (Burg et al., 1989). The PCRs were conducted in $100 \mu \mathrm{l}$ of reaction mixture consisting of $20 \mathrm{mM}$ ammonium sulphate, $75 \mathrm{mM}$ Tris HCL, $\mathrm{pH}$ 9.0, 0.01 percent Tween $20(\mathrm{w} / \mathrm{v}), 2.5 \mathrm{mM}$ magnesium chloride, $0.1 \mathrm{mM}$ dNTPs, $0.2 \mu \mathrm{M}$ each primer, 1 unit Taq polymerase (Promega). The primers and the amplification conditions were as described by (Wastling 1993) except that the denaturing, annealing and extension times were each one minute. In the first PCR, the primers were GGAACTGCATCCGTTCATGAG and TCTTTAAAGCGTTCGTTCGTGGTC. Following the successful amplification of a 193 base-pair product, $1 \mu 1$ of each reaction was used in a second PCR, with a new primer pair, TGCATAGGTTGCAGTCACTG and GGCGACCAATCTGCGAATACACC, to produce a 94 base-pair amplification product. The products were visualized after electrophoresis of $30 \mu \mathrm{l}$ of reaction mixture on $2 \%$ agarose gels by staining with ethidium bromide. T. gondii DNA was used as positive control. Distilled water and uninfected tissues were used as negative controls and were run with tests to monitor for cross-contamination. 


\section{RESULTS}

The effects of treatment with CLI and SD combined in five different doses on the survival of mice infected with $10^{3} \mathrm{RH}$ strains $T$. gondii tachyzoites were compared to those of the same drugs given alone.

Effect of SD \& CLI alone on experimental animals was showed in the following Table (1):

Table 1: Shows effect of SD and CLI alone on experimental animals.

\begin{tabular}{|c|c|c|c|}
\hline \multirow{2}{*}{ Drug } & \multicolumn{3}{|c|}{ Dose } \\
\cline { 2 - 4 } & $25 \mathrm{mg} / \mathrm{kg} /$ day & $50 \mathrm{mg} / \mathrm{kg} /$ day & $100 \mathrm{mg} / \mathrm{kg} /$ day \\
\hline \multirow{2}{*}{ SD } & $0 \%$ & $16 \%$ & $12 \%$ \\
\hline CLI & $62 \%$ & $69 \%$ & $88 \%$ \\
\hline
\end{tabular}

* SD alone was effective compared with no treatment and when it was given at 50 or 100 $\mathrm{mg} / \mathrm{kg} / \mathrm{day}$, it resulted in 8 -week survival of 16 or $12 \%$ of mice, respectively.

* CLI alone at 25,50 , or $100 \mathrm{mg} / \mathrm{kg} / \mathrm{day}$ led to survival of 62,69 , or $88 \%$ of mice, respectively.

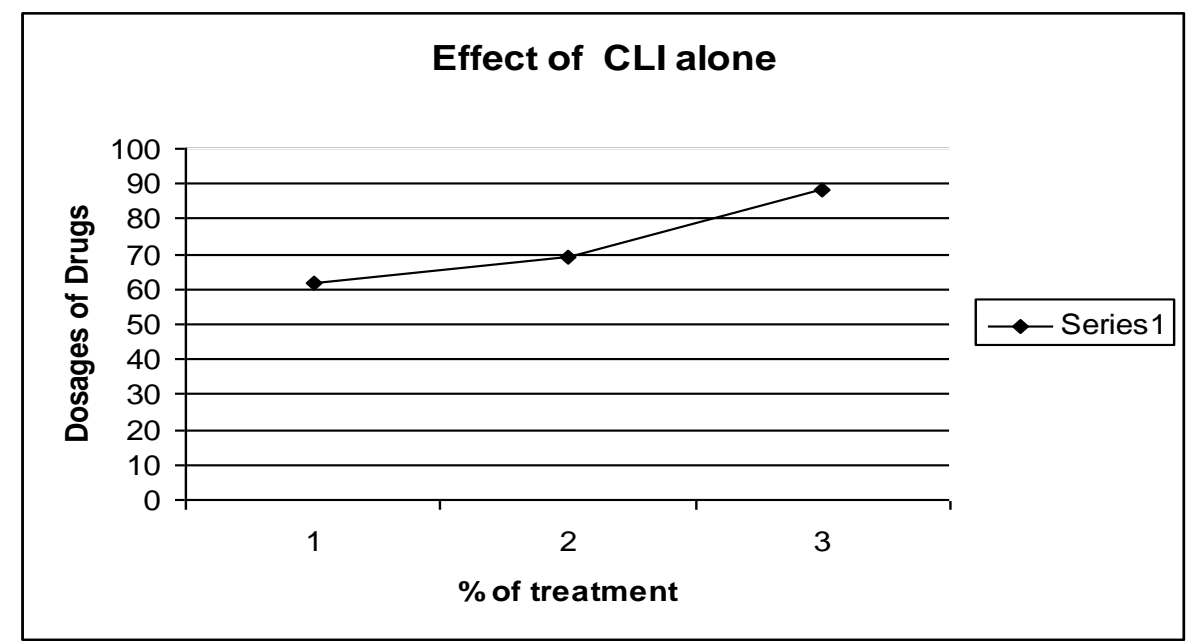

Fig. 1 Diagram of the effect of CLI 


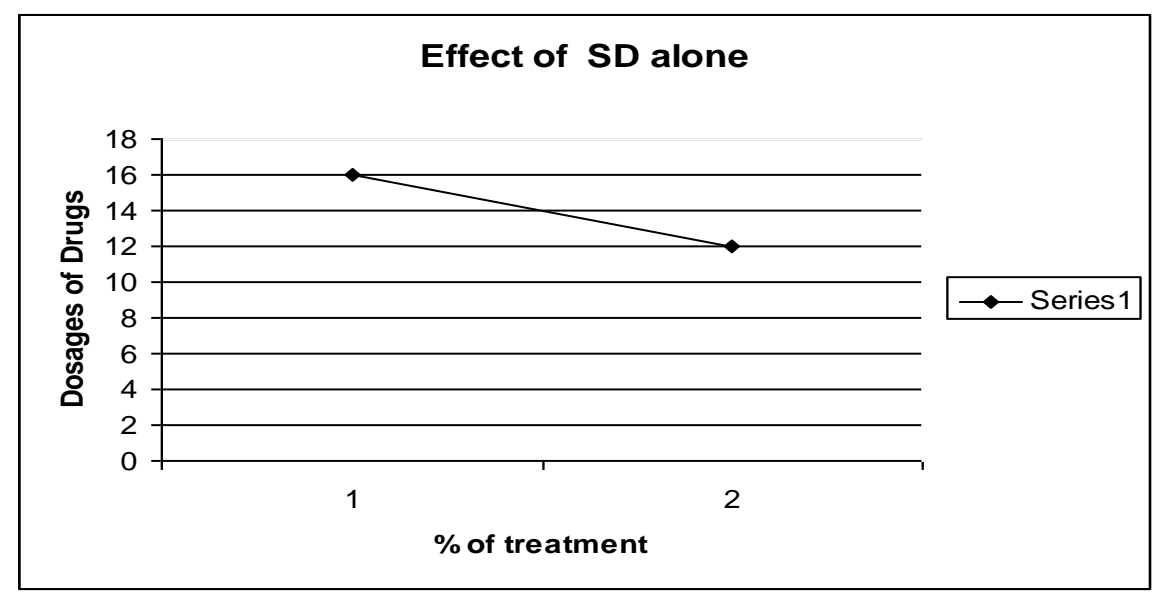

Fig. 2 Diagram oh the effect of SD:

Effect of SD and CLI combined on experimental animals was showed in the following Table (2):

Table 2: Shows effect of SD and CLI combination on experimental animals:

\begin{tabular}{|c|c|c|c|c|c|}
\hline \multirow{2}{*}{ Drug } & \multicolumn{5}{|c|}{ Dose } \\
\cline { 2 - 6 } & $\begin{array}{c}25+25 \\
\mathrm{mg} / \mathrm{kg} / \mathrm{day}\end{array}$ & $\begin{array}{c}25+50 \\
\mathrm{mg} / \mathrm{kg} / \mathrm{day}\end{array}$ & $\begin{array}{c}50+50 \\
\mathrm{mg} / \mathrm{kg} / \mathrm{day}\end{array}$ & $\begin{array}{c}50+100 \\
\mathrm{mg} / \mathrm{kg} / \mathrm{day}\end{array}$ & $\begin{array}{c}100+100 \\
\mathrm{mg} / \mathrm{kg} / \mathrm{day}\end{array}$ \\
\hline SD+CLI & $62 \%$ & $83 \%$ & $87 \%$ & $89 \%$ & $90 \%$ \\
\hline
\end{tabular}

*Treatment with SD and CLI combined at, 25 plus 25, 25 plus 50, 50 plus 50, 50 plus 100 and 100 plus $100 \mathrm{mg} / \mathrm{kg} /$ day protected $62,83,87,89$, and $90 \%$ of mice, respectively, with no significant variation among particular groups.

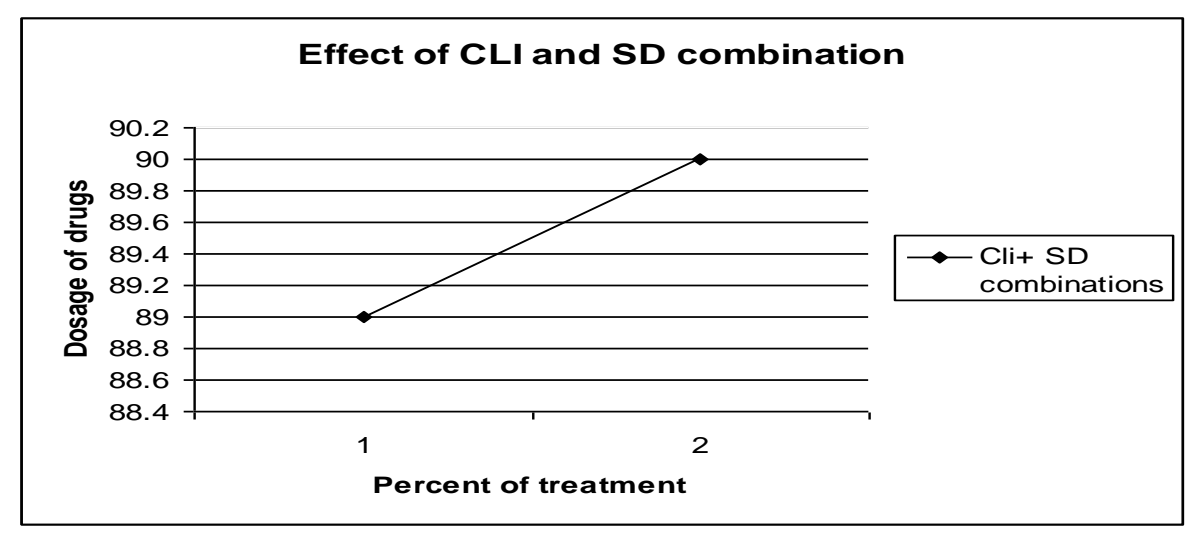

Fig. 3 Diagram of the effect of CLI\&SD combination 
However, all drug combinations were significantly more effective than any dose of SD alone.

The efficacy of CLI alone, the addition of SD to any given dose of CLI, including those at which the effect of the combined drugs was apparently better). Thus, the combined drugs exhibited a simple additive effect.

Treatment with SD and CLI combined at 25 plus 25,25 plus 50,50 plus 50,50 plus 100 or 100 plus $100 \mathrm{mg} / \mathrm{kg} /$ day protected $62,83,87,89$, or $90 \%$ of mice,.

The drug combinations were more effective than any dose of SD alone. This was not the case when the two drugs combined were compared with CLI alone. Given the efficacy of CLI alone, the addition of SD to any given dose of CLI, including those at which the effect of the combined drugs was apparently better. The combined drugs exhibited a simple additive effect.

Table 3: Shows the residual infection in mice treated by Clindamycin with sulfa, groups

\begin{tabular}{|c|c|c|c|c|c|}
\hline \multirow[t]{2}{*}{ No. of parasites } & \multirow[t]{2}{*}{$\begin{array}{c}\text { SD + CLI dose } \\
(\mathrm{mg} / \mathrm{kg} / \text { day })\end{array}$} & $\begin{array}{c}\text { No +ve } \\
/ \\
\text { No. } \\
\text { Bioassay } \\
\text { (4 wk P.i.) }\end{array}$ & $\begin{array}{c}\text { No +ve } \\
/ \\
\text { No } \\
\text { Bioassay } \\
\text { (4 wk P.i.) }\end{array}$ & $\begin{array}{c}\text { No +ve } \\
/ \\
\text { No } \\
\text { PCR } \\
\text { (8wk P.i.) }\end{array}$ & $\begin{array}{c}\text { No+ve } \\
/ \\
\text { No. } \\
\text { PCR } \\
\text { (8 wk P.i.) }\end{array}$ \\
\hline & & P.o & I.p & Brain & Lungs \\
\hline $10^{3}$ & Low $25+25$ & ND & ND & $1 / 2$ & $0 / 2$ \\
\hline $10^{3}$ & High100+100 & $2 / 2$ & $1 / 2$ & $1 / 2$ & $0 / 2$ \\
\hline
\end{tabular}

P.i.: post infection. P.o.: per oral infection. I.p. intrapretoneal ND: not done.

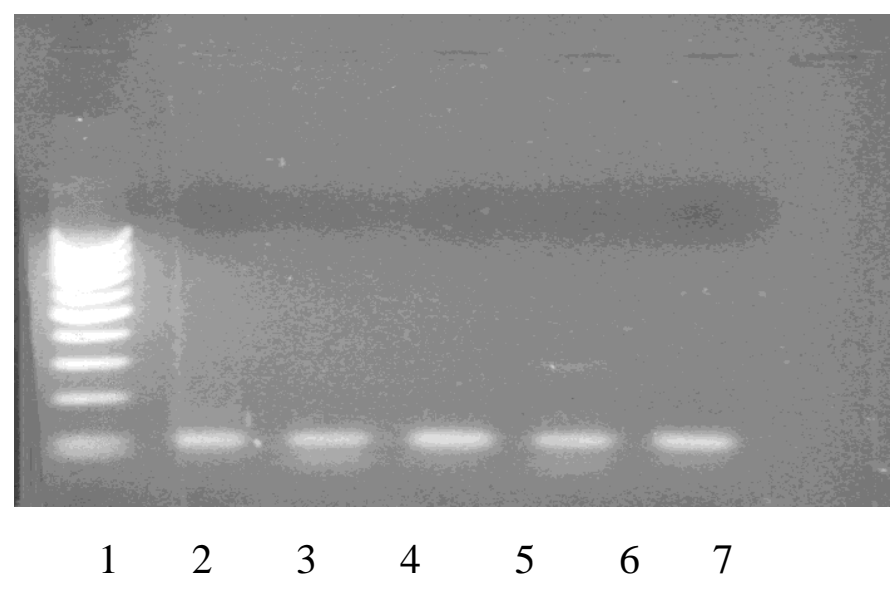

Fig. 4 Showing electrophoretic pattern of the second PCR product (194 bp) 
Lane 1: DNA marker, Lane2: positive control (extracted DNA of T.gondii Spp), Lane 3, 4, 5 and 6: amplified T.gondii Spp DNA in r tissue samples. Lane 7: negative control.

Lethal events were recorded following both i.p. and per oral inoculation of brain tissue, suggesting the presence of both the tachyzoite and bradyzoite life stages of the parasite in some survivors at that time.

\section{DISCUSSION}

The Experiments were performed in vivo in a mouse model of acute toxoplasmosis to evaluate the effectiveness of the combination Clindamycin/Sulfadiazine. Each Clindamycin or Sulfadiazine alone provides weak protection against toxoplasmosis, while the combination of the two drugs has significantly synergistic actions. The results of the study showed the importance of using in the treatment of CLI\&SD on Toxoplasmosis either alone or combination. Drug combinations were more effective than any dose of SD alone. The combination of CLI and SD acts synergistically against $T$. gondii infection.

The results presented show SD and CLI to be a promising drug combination with the potential to eliminate the parasite, therefore warranting further investigation. The synergistic effect was remarkable in infections with $10^{3}$ parasites, in which 14-day treatment with combinations of 25 and $50 \mathrm{mg}$ of CLI and SD / $\mathrm{kg} /$ day protected 62 to $87 \%$ of animals by week 8 , whereas the same doses of either CLI or SD alone could not prevent mortality. Moreover, the effect of a combination of $50 \mathrm{mg}$ of $\mathrm{CLI} / \mathrm{kg} /$ day with either 25 or $50 \mathrm{mg}$ of SD $/ \mathrm{kg} /$ day was similar to the effect of $100 \mathrm{mg}$ of CLI $/ \mathrm{kg} /$ day alone. This potential is emphasized by the fact that the mere presence of $T$. gondii DNA does not necessarily indicate the presence of viable parasites able to induce infection. This agreed with the opinion of it implies immune control of infection. Thus, in the treated, apparently healthy mice in which $T$. gondii DNA was detected, drug treatment, by reducing the initial parasite burden, may have provided the time for

Protective immunity against an otherwise lethal parasite infection to develop; a delayed specific T-cell response has been associated with treatment (Murray et al., 1993). (Paniker 2002, Leport et al., 1988) stated that the low doses used to obtain high protection and cure rates may allow prolonged administration; 4- and 8-week courses of SD were shown to be effective in chronic murine toxoplasmosis and (Nikolić et al., 1999) shown also that the effect of CLI critically depends on treatment duration. 
(Dannemann et al., 1992) were successfully treated for brain abscess with Clindamycin and sulfadiazine.

Furthermore, adverse side effects of CLI (Dannemann et al., 1992). (Dannemann et al., 1988) (Katlama et al., 1996; Pfefferkorn et al., 1993). May be reduced by the use of lower doses, and SD is generally well tolerated. However, to appreciate the potential of the combination of CLI and SD in the treatment of human disease, studies of the levels of the drugs achieved in serum and tissues with the regimens used, relative to the doses feasible in human therapy, are needed.

It should be bear in mind the limitations of extrapolating data from animal models to the human situation; significantly enhanced the effect of the combined drugs may offer direction for future clinical trials of the antiT. gondii potential of this drug combination.

It is difficult to put these results in perspective by comparing them with the efficacy of these or other drugs, alone or in combination, obtained in other animal models, since the infection and treatment protocol characteristics vary widely.

\section{REFERENCES}

$A A P O$, : American Association for Pediatric Ophthalmology and Strabismus.

Antonion, M.; Tselentis, Y.; Babalis, T.; Gikas, A.; Stratigakis, N.; Vlachonikolis, I.; Kafatos, A. and Fioretos, M. (1995): The seroprevalance of ten zoonoses in two villages of Crete, Greece. Eur. J. Epidemiol. 11: 415-423.

Araujo, G.; Lin, T. and Remington, J.S. (1992): Synergistic combination of azithromycin and sulfadiazine for treatment of toxoplasmosis in mice. European Journal of Clinical Microbiology and Infectious Diseases 11, 1, 71-73.

Araujo, F.G. and Remington, J.S. (1974): Effect of Clindamycin on acute and Chronic toxoplasmosis in mice. Antimicrob Agents Chemother. 5: 647-651.

Araujo, F.G.; Slifer, T. and Remington, J.S. (1994): Rifabutin is active in murine models of toxoplasmosis. Antimicrob. Agents Chemother. 38: 570-575.

Araujo, F.G.; Huskinson, J. and Remington, J.S. (1991): Remarkable in vitro and in vivo activities of the hydroxynaphthoquinone, 566C80, against tachyzoites and tissue cysts of Toxoplasma gondii. Antimicrob. Agents Chemother. 35: 293-299 
Araujo, F.G.; Huskinson-Mark, J.; Gutteridge, W.E. and Remington, J.S. (1992): Invitro and in vivo activities of the hydroxynaphthoquinone $566 \mathrm{C} 80$ against the cyst form of Toxoplasma gondii. Antimicrob Agents Chemother. 36: 326-330.

Araujo, F.G.; Lin, T. and Remington, J.S. (1993): The activity of atovaquone $(566 \mathrm{C} 80)$ in murine toxoplasmosis is markedly augmented when used in combination with pyrimethamine or sulfadiazine. J. Infect Dis. 167: 494-497.

Barakat, A.M.A; Abd-Elaziz, M.M. and El Fadaly, H.A. (2009): Comparative diagnosis of toxoplasmosis in Egyptian small ruminants by indirect Haemagglutination assay and ELISA. Global Veterinaria 1, 3: 7-14.

Burg, J.L.; Grover, C.M.; Pouletty, P. and Boothroyd, J.C. (1989): Direct and sensitive detection of a pathogenic protozoan, Toxoplasma gondii, by polymerase chain reaction. J. Clin. Microbiol. 27: 1787-1792.

Daniel, I.; Simon, MD.; Frank, C.; Brosius, III; MD, David, M. and Rothstein, MD. (1990): The Treatment of Toxoplasma Encephalitis in Patients With Acquired Immunodeficiency Syndrome (Sulfadiazine Crystalluria Revisited. Arch Intern Med. 150(11): 2379-2384.

Dannemann, B.; McCutchan, J.A.; Israelski, D.; Antoniskis, D.; Leport, C.; Luft, B.; Nussbaum, J.; Clumeck, N.; Morlat, P.; Chiu, J.; Vilde, J.L.; Orellana, M.; Feigal, D.; Bartok, A.; Heseltine, P.; Leedom, J. and Remington, J.S. (1992): The California Collaborative Treatment Group. Treatment of toxoplasmic encephalitis in patients with AIDS. A randomized trial comparing pyrimethamine plus clindamycin to pyrimethamine plus sulfadiazine. Ann Intern. Med. 116: 33-43.

Dannemann, B.; Israelski, D.M. and Remington, J.S. (1988): Treatment of toxoplasmic encephalitis with intravenous clindamycin. Arch Intern. Med. 148: 2477-2482.

Dubey, J.P. (1981): Toxoplasma-induced abortion in dairy goats. J. Am. Vet. Med. Assoc. 187: 671-674.

Dubey, JP.; Brown, CA.; Carpenter, JL. and Moore, JJ. (1992): Fatal toxoplasmosis in domestic rabbits in the USA. Vet. Parasitol. 44: 305-309.

Filice, G.A. and Pomeroy, C. (1991): Effect of Clindamycin on pneumonia from reactivation of Toxoplasma gondii infection in mice. Antimicrob. Agents Chemother. 35: 780-782. 
Fitzhugh, A.L. (1998): Antibiotic inhibitors of the peptidyl transferase center. 1. Clindamycin as a composite analogue of the transfer RNA fragments L-Pro-Met and the D-ribosyl ring of adenosine. Bioorg. Med. Chem. Lett. 8: 87-92.

Gormley, P.D.; Pavesio, C.E.; Minnasian, D. and Lightman, S. (1998): Effects of drug therapy on toxoplasma cysts in an animal model of acute and chronic disease. Investig Ophthalmol. Vis. Sci. 39: $1171-1175$.

Hassanain, M.A.; Ahmed, W.M. and Abd El-Aziz, M.M. (1996): Toxoplasmosis in relation to genital diseases in Egyptian buffaloes. Egypt. J. Appl. Sci. 11: 286-295.

Haverkos, H.W. (1987): The TE:study group. Assessment of therapy for toxoplasma encephalitis. Am. J. Med. 82: 907-914.

Hejlicek, K. and Literak, I. (1995): Animal sources and transmission of Toxoplasma gondii. Epidemiologie-Mikrobiologie-Immunologie. 44: 121-126.

Johnson, AM. (1990): Toxoplasma, biology, pathology, immunology and treatment. In: P.L. Long (ed). Coccidiosis of Man and Domestic Animals, CRC Press, Boca Rotan, FL, pp. 121-153.

Katlama, CB.; Mouthon, D.; Gourdon, D. and Lapierre F. Rousseau(1996) The Atovaquone Expanded Access Group. Atovaquone as longterm suppressive therapy for toxoplasmic encephalitis in patients with AIDS and multiple drug intolerance. AIDS. 10: 1107-1112.

Leport, C.F.; Raffi, S.; Matheron, C.; Katlama, B.; Regnier, A.G.; Saimot, C.; Marche Vedrenne, C. and Vilde, J.L. (1988): Treatment of central nervous system toxoplasmosis with pyrimethamine/ sulfadiazine combination in 35 patients with the acquired immunodeficiency syndrome. Efficacy of long-term continuous therapy. Am. J. Med. 84: 94-100

Louis M. Weiss; Benjamin J. Luft; Herbert B. Tanowitz and Murray Wittner (1999): Primethamine Concentrations in Serum during Treatment of Acute Murine Experimental Toxoplasmosis. Am. J. Trop. Med. Hyg. 46: 288-291.

Maniatis, T.; Fritsch Sambrook, E.F. (1982): J. Molecular cloning: a laboratory manual. Cold Spring Harbor, N.Y: Cold Spring Harbor Laboratory; 1982. Pp. 545.

McMaster, P.R.B.; Powers, K.G.; Finerty, J.F. and Lunde, M.N. (1973): The effect of two chlorinated lincomycin analogues against acute toxoplasmosis in mice. Am. J. Trop. Med. Hyg. 22: 14-17. 
Murray, H.W. and Teitelbaum Hariprashad, R. (1993): J. Response to treatment for an intracellular infection in a T-cell-deficient host: toxoplasmosis in nude mice. J. Infect. Dis. 167: 1173-1177.

Nikolić, T.; Djurković-Djaković, O.; Bobić, B.; Nikolić, A. and Babić, D. (1999): Treatment protocol determines the efficacy of clindamycin in acute murine toxoplasmosis. Int. J. Antimicrob. Agents.11: 145-149.

Obata, K. (1996): Phylum Apicomplexa: Gregarines, coccidia and related organisms. In: Roberts, L.S.; Janovy, J.Jr. (eds). Foundation Parasitology. 5th ed., Wm. C. Brown Publishers. Parasitology 30: 1217-1258.

Paniker, CKJ. (2002): Text Book of Medical Parasitology $5^{\text {th }}$ ed. Miscellaneous sporozoa and microspora. Jaypee Brother: Medical publishers (P) LTD ,New Delhi., pp:89-96.

Pfefferkorn, E.R.; Nothnagel, R.F. and Borotz, S.E. (1992): Parasiticidal effect of clindamycin on Toxoplasma gondii grown in cultured cells and selection of a drug-resistant mutant. Antimicrob. Agents Chemother.36:1091-1096.

Pfefferkorn, E.R. and Borotz, S.E. (1994): Comparison of mutants of Toxoplasma gondii selected for resistance to azithromycin, spiramycin, or clindamycin. Antimicrob. Agents Chemother. 38: 31-37

Pfefferkorn, E.R.; Borotz, S.E. and Nothnagel, R.F. (1993): Mutants of Toxoplasma gondii resistant to atovaquone (566C80) or decoquinate. J. of Parasitology 79: 559-564

Piketty, CF.; Derouin Rouveix, B. and Pocidalo, JJ. (1990): In vivo assessment of antimicrobial agents against Toxoplasma gondii by quantification of parasites in the blood, lungs, and brain of infected mice. Antimicrob. Agents Chemother. 34: 1467-1472.

Romand, S.; Della Bruna, C.; Farinotti, R, and Derouin, F. (1996): In vitro and in vivo effects of rifabutin alone or combined with atovaquone against Toxoplasma gondii. Antimicrob. Agents Chemother. 40: 2015-2020.

Tenter, A.M.; Heckeroth, AR. and Wiess, L.M. (2000) Toxoplasma gondii: from animals to humans. International. Journal of Parasitol. 30(12-13): 1217-58.

Tenter, AM.; Vietmeyer, C. and Johnson, A.M. (1992): Development of ELISA based on recombinant antigens for the detection of Toxoplasma gondii-specific antibodies in sheep and cats. Vet. Parasitol. 43: 189-201. 
Tsai, HC.; Lee, SS.; Lin, HH.; Lin, WR.; Chen, YS.; Huang, CK.; Liu, YC.; Chen, ER. (2002) Treatment of Toxoplasma brain abscess with clindamycin and sulfadiazine in an AIDS patient with concurrent atypical Pneumocystis carinii pneumonia. J. Formos. Med. Assoc.101(9): 646-9.

Vuković, D.; Djurković-Djaković, O.; Kovaĉević, S.; Bobić, B.; Nikolić, A.; Todorović, V.; Babić, D (1997): Effect of clindamycin in a murine model of acute toxoplasmosis. Clin. Microbiol. Infect. 3:89-94.

Wastling, JM.; Nicoll, S. and Buxton, D. (1993): Comparison of two gene amplification methods for the detection of Toxoplasma gondii in experimentally infected sheep. J. Med. Microbiol. 38: 360-365. 